\title{
The spiritual world, Christ, ancestors, angels, and demons in Hlungwani's art and theology
}

\author{
Dr Raita Steyn \\ Faculty of Education \\ University of Pretoria, South Africa \\ Email: raita.steyn@up.ac.za \\ Orcid number: https://orcid.org/0000-0002-7506-8179 \\ Doi: https://doi.org/10.46222/pharosjot.102.110
}

\begin{abstract}
Jackson Hlungwani's vision of a New Jerusalem is shaped by his unique African Christian theology teachings. They are expressed through his wooden sculptures in an "independent African Church which would echo the wish to Africanize Christianity and represent a new cultural and spiritual phenomenon through his art" (Rankin, 1998: 46; Steyn, 2019: 184). It is through this vision and his artworks that Hlungwani prophesied the coming of an Apocalypse, which would result in man's salvation, and signify an ultimate victory over evil. This article concerns the New Jerusalem (the 'imagined' and the 'built') and reveals Hlungwani's Christian and traditional ideas around the spiritual world, Christ, the ancestors, angels, and demons. Hlungwani's vision of a New Jerusalem should therefore be understood in the context of a unique African Christian theology created from the perspective of an African cultural context. The two altars for the New Jerusalem site and a number of wooden artworks are selected for their connection with both the artist's vision and the supernatural world, angels, ancestors, and earthly warriors. The selected sculptures are the Crucifix IV, the sculpture God and Christ, and the panel Cain and Abel. They are discussed and analyzed as I believe that they reflect profound visual metaphors derived from spiritual visions, the visions of the Prophet Ezekiel, and of the Apocalypse of Saint John from the final book of the Christian Bible, the Book of Revelation.
\end{abstract}

Keywords: African Christian theology, ancestors, New Jerusalem, Shangaan warriors, Zionist Christian Church (ZCC).

\section{Jackson Hlungwani: a short overview}

Sculptor, spiritual leader and healer, Jackson Hlungwani (1923-2010) (Figure 1) was born to a Tsonga-speaking family in Mashampa Village in Venda. However, before 1948 they were removed by force to Mbhokota in what is now Limpopo (for a time Mbhokota was in the independent homeland of Gazankulu) owing to the policies of racial segregation in South Africa.

In 1941, Hlungwani was employed as a migrant worker in Johannesburg. However, three years later, he lost a finger in a work-related accident and decided to return to Limpopo (Hayashida, 2000: 71). The loss of his finger has had an impact on his theology, which will be discussed later. In 1944, Hlungwani joined the Zionist Christian Church (ZCC), and two years later, was ordained as a priest. While working on an irrigation scheme near the town of Louis Trichardt (Schneider, 1989: 11), Hlungwani developed abscesses on both legs ${ }^{1}$, and vowed

\footnotetext{
${ }^{1}$ However, Maluleke $(1991,17)$ writes that Hlungwani's sister told that the latter had ulcers on his right leg from when he was a boy.
} 
that it was the demon, Satan himself, who had shot him. His 'encounter' with the demon was the beginning of his life-time spiritual change. He relates how he managed to take out 'the arrow' in his left leg, while the other became a poisonous snake, penetrating his lower right leg, leaving a permanent abscess and making him severely ill. Seemingly not finding either healing or spiritual fulfilment at the ZCC, he left in 1978 with the anticipation of finding a "true religion" (Maluleke, 1991: 30; Nettleton, 2009: 54).

Hlungwani's metaphysical experiences started in the same year, in fact on the day that he contemplated ending his life as he could no longer bear the dreadful pain in his leg. In a theophany on the evening before his intended suicide, Christ, accompanied by two men or angels, appeared and rescued him from his deadly endeavour.

Hlungwani recalled his conversation with Christ and three promises that were given to him: i) he would be healed, ii) he would serve God all his life, and iii) he would see God step past him. And indeed, in his vision, Hlungwani saw God's lower legs moving above the ground, pass him by (Schneider, 1989: 60). This vision and the theophany, in addition to the breaking away from the ZCC, motivated Hlungwani to create his own church and transform the unseen into the concrete, that is, wooden sculptures which upholds his close connection with God. In addition to his sculptures, Hlungwani also created two altars with carved wooden sculptures placed on stone platforms: the Altar of God (men's altar) and Altar of Christ (women's altar). These were adorned with carvings of Christ, ancestors, angels, and other biblical themes, in other words, they all expressed a metaphysical content. The wooden sculptures Crucifix I and IV, God and Christ, as well as the wooden panel Cain and Abel, which were not part of the Altars, are also discussed and their symbolic meanings analyzed in this article.

I will first critically analyse the above mentioned art work of Hlungwani through a descriptive, comparative approach as well as (re-)examine them in the context of Biblical scriptures and the political-religious background of the sculptor's time and life. The written sources about Hlungwani's life and artworks come partly from himself through interviews and mainly from the many studies, catalogues, articles, books and pamphlets which have been published or which have been preserved as manuscripts in libraries, museums, exhibition halls and universities. They have been listed (partly) in the publications, attached at the end of my article as references, and will be published in full in the forthcoming book by Burroughs, Leibhammer and Nel.

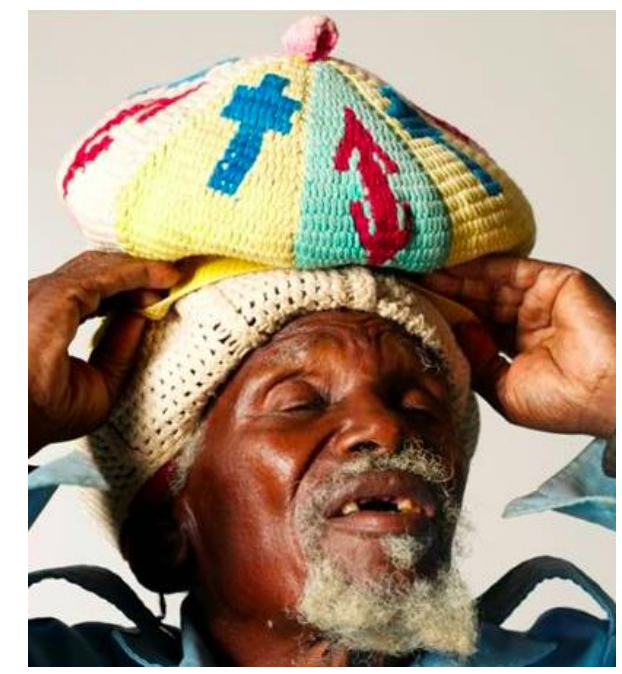

Figure 1: Jackson Hlungwani wearing his Rastafarian cap. Photograph: courtesy Merwelene van der Merwe. 


\section{Crucifixes, God and Christ, and Hlungwani's ancestors}

\section{i. Crucifixes}

Some of the first carved sculptures to emerge from the 1960s are Hlungwani's Crucifixes (Becker, 1989: 23). The faces of Christ on the Crucifixes (I-IV) are possibly self-portraits of Hlungwani (Figure 2), thereby asserting his closeness to the subject-matter by personalising Christ's suffering with his own suffering, as he had undergone "a spiritual as well as physical metamorphosis" (Maluleke, 1991: 20). Hlungwani-Christ is depicted with long hair and a beard, and the expected traditional crown of thorns is replaced, according to Becker (1989: 22), with a Tsonga head-ring, symbolising "maturity, wisdom and leadership". Based on closer observation, I believe that the crown of thorns is accompanied by the sculptor's own Rastafarian-coloured cap (Maluleke, 1991: 16), which is found immediately above the crown or Tsonga head-ring.
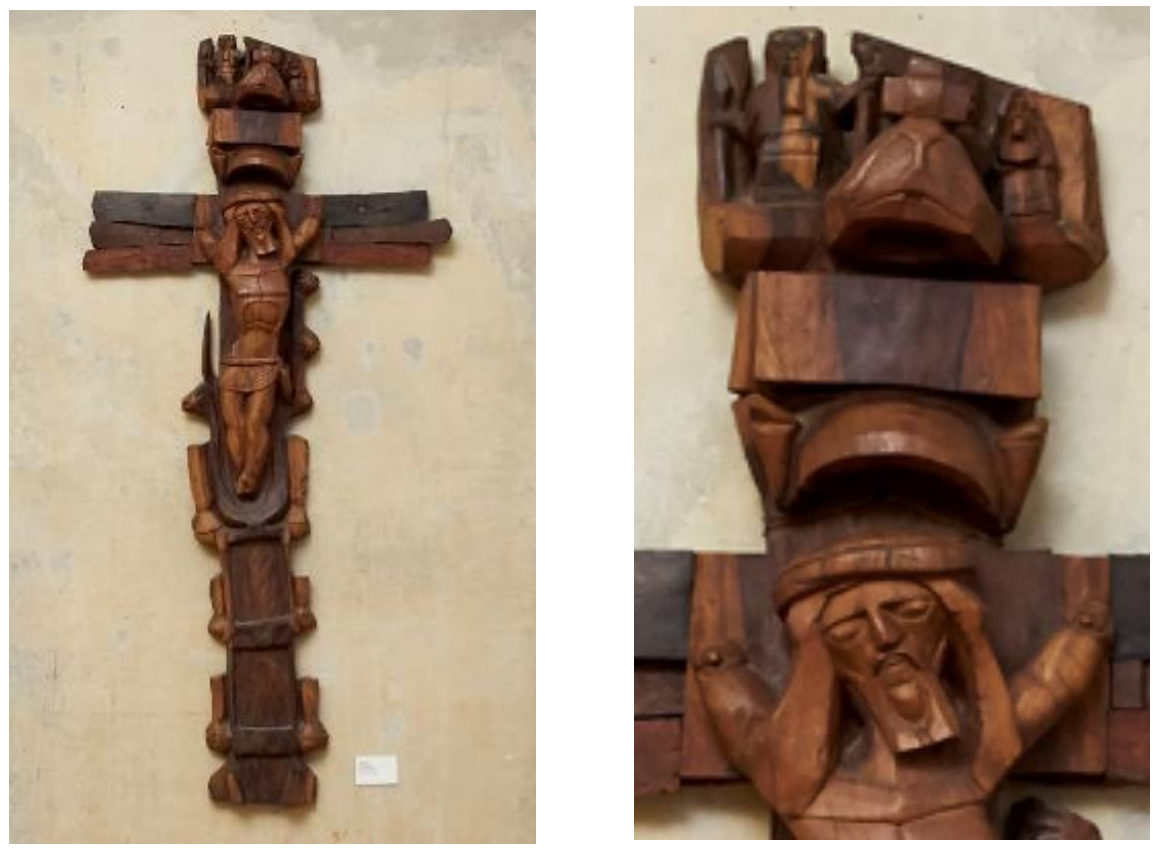

Figure 2: left: Crucifix (IV), right: detail. Photograph: Raita Steyn, courtesy Norval Foundation.

On the uppermost section of Crucifix IV (Figure 3), on either side of a heavenly crown, stand two nameless, bearded celestial figures. This scene is reminiscent of the visual presentations of the Holy Trinity crowning the Virgin Mary, an image commonly found in iconography. Nevertheless, Becker (1989: 23, n. 4) believes that these two bearded figures, "may well be God and Gabriel", as Hlungwani himself said that the determining factor was the length of the beards: "God's beard is the longest, then Gabriel's as he was God's first born and Christ's beard is the shortest as he was the last born." By looking closely, one clearly sees an image of two prophets, which I believe could be Moses and Elijah on Mount Tabor, based on the Transfiguration of Christ as retold in Matthew 17:3-5:

Just then there appeared before them Moses and Elijah, talking with Jesus. Peter said to Jesus, 'Lord, it is good for us to be here. If you wish, I will put up three shelters-one for you, one for Moses and one for Elijah.' While he was still speaking, a bright cloud covered them, and a voice from the cloud said, 'This is my Son, whom I love; with him I am well pleased. Listen to him!" 
In the above passages, God, the Father, pleased with Christ, his Son, instructs the disciples to listen to Him. This may indirectly refer to Hlungwani himself as a prophet, who believes himself to be one of God's sons and messenger, and who also believes that God is pleased with him. In an interview with Maluleke (1991), Hlungwani told him how a voice instructed him to build a temple for God:

Out of the blue, lo and behold, the Word came to Hlungwani [sic] and said: 'Return to your roots, near the burial site of your father and build me a temple in which you must include heavenly and earthly lives in your worship'. (Maluleke 1991: 30-31).

Christian theology assigns a great deal of significance to the Transfiguration in the sense that the mountain presents the point where human nature meets God, the seen with the unseen, and the temporal with the eternal. Christ himself is the intermediary between heaven and earth, and "as a prophet, Jesus is the bearer of God's Word to the Israelites" (Nicolaides, 2020: 9).

The above is confirmed in an interview with Hayashida (2000: 12), where Hlungwane [sic] revealed that he had a "personal relationship with "Christa." He spoke of "going up to be with God" and "coming back to teach all nations." In a previous interview, Markovitz (1989) mentioned Hlungwani's closeness to God, stating that "Number one is God. Number two is Christ. Number three is Jackson" (Steyn 2019: 186); hereby affirming his link with the Holy Trinity, through the role that his ancestor, his grandfather Bhandi Pavalala, played. Hlungwani perhaps justified his linkage with the Holy Trinity through his immediate contact with his grandfather, Bhandi Pavalala, which, according to Maluleke (1991: 12), is believed to be a sacred Shangaan/Tsonga name or name of the gods. This name was given to Hlungwani at birth a week after his grandfather's death, who thus believed that his grandfather was reborn in him. Maluleke (1991: 13) affirms that "sacred names in the Tsonga society [are] part and parcel of the Tsonga's religious life." In the Zionist context, Cavallo (2013: 12-13) is of the opinion that when the descendants or offspring share their ancestors' names, they "are part of a living individual." This confirms Anderson's (2000: 198) indication that in many Pentecostal churches, the Holy Spirit has taken on the role of the ancestors. Cavallo (2013: 12) furthermore states that the Zionists connect angels with the ancestors, as angels, being present in their lives, help and guide them and "channel messages through dreams, visions or simple voiceguide[s]". Equally, in an interview with Schneider (1989: 61), Hlungwani claimed that Christ in spirit communicated directly with him through his preaching and sculptures. Hlungwani went as far as baptising himself Xidonkane xa Jesu (Tsonga for 'donkey of Jesus') (Maluleke, 1991: 14; Nettleton, 2009: 54), suggesting his connection with the donkey who carried Mary and the unborn Christ to Bethlehem and later the donkey who carried Christ on his triumphal entry into Jerusalem. In this way, his closeness to the life and death of Christ was symbolized. Maluleke (1991: 2) described Hlungwani as "a person with a multitude of personalities", and indeed Hlungwani himself believed that he was "a direct descendant of a long line of prophets that included John the Baptist" (Maluleke, 1991: 41). To prove this, he showed Maluleke a copy of a fourteenth-century biblical illustration of John the Baptist comparing his own missing finger with the one 'missing' in the image of the disciple.. The finger purportedly symbolized the devil that was now removed from Hlungwani's life (Maluleke, 1991: 41, after Leshoai). Whether Hlungwani is an artist or a prophet, Number Three, Bhandi Pavalala, Xidonkane, or a descendant of John the Baptist does not matter, what matters is that his spiritual world forms part of his living world and that of the Incarnation, Death, and Resurrection of Christ.

The presence of the prophets Elijah and Moses on top of Crucifix IV (Figure 3) attests to Hlungwani's understanding of their relationship in the context of Scripture. Moses and Elijah, according to Origen, were representatives of the "Law and the Prophets" respectively (Matthew 5:17-19). Elijah, placed on Christ's right, holds a staff in the one hand and a spear in the other, and Moses on Christ's left holds the law or the commandments. According to 
Nicolaides (2020: 4), "Moses symbolizes the dead and Elijah, given that he was carried up to heaven in a chariot of fire, represents the living." Christ being crucified metaphorically fulfils the "law and the prophets". Therefore, Crucifix IV depicts a victory over death rather than defeat - effectively a symbolic death and rebirth in Hlungwani's life. Nicolaides (2020:4) states that, "The Transfiguration brings to us a jubilant message, and a confirmation that God is indeed accessible to any personal experience." I believe the reason for choosing these two figures is once again a reflection of Hlungwani's closeness to God, "underlining his interaction between his two worlds: the one we live in, that is the concrete one, and the other one, associated with the metaphysical, the abstract" (Steyn, 2019: 186).

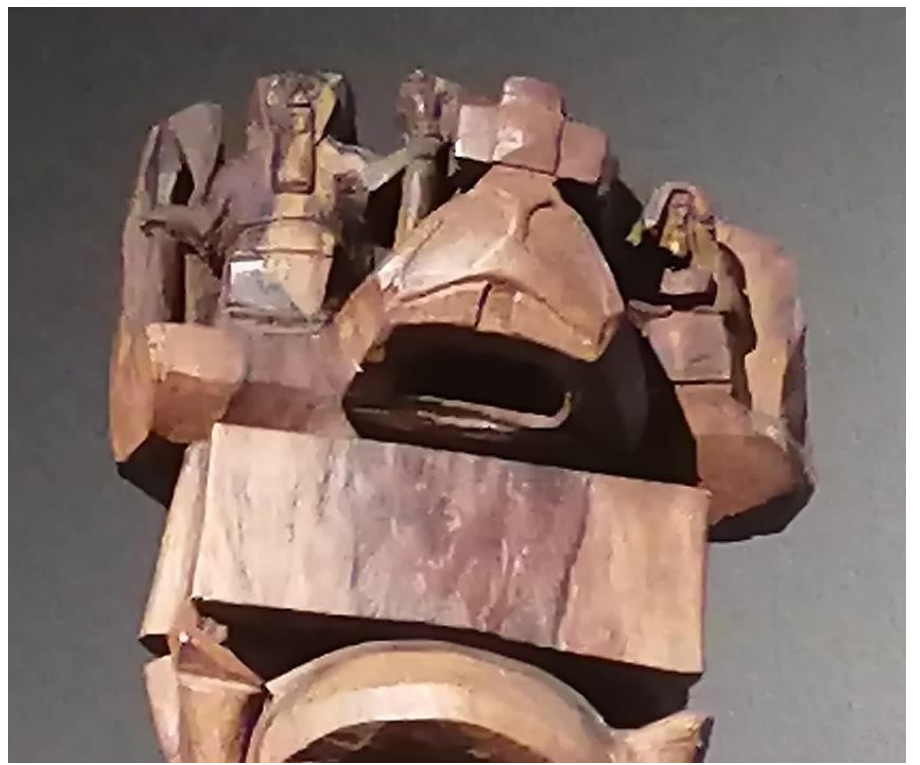

Figure 3: Detail of Crucifix IV: two nameless, bearded celestial figures on either side of a heavenly crown. Photograph: Raita Steyn, courtesy Norval Foundation

\section{ii. God and Christ}

Hlungwani clearly understood the unity of the Father, the Son, and the Holy Spirit as three persons united in one Godhead. As such, he created a sculpture titled God and Christ, with the Holy Spirit carved in the shape of a double-headed Byzantine bird on top of the Godhead. The base of the united God and Christ sculpture (Figure 4) manifests three unusual carvings of creatures. Spiro (1992: 72) describes them as "a lion, small lion and a cow". Alternatively, and as a result of close investigation of the sculpture, I suggest that these zoomorphic forms are, an ox or a calf to the left; a bird with its wings spread wide open in the middle; and a lion to the right. This single group of figures, together with the united God and Christ figure portrayed as a human, represent the symbols of the four Evangelists, Matthew, Mark, Luke, and John. The four animal figures derive from Ezekiel 1:10 and the Book of Revelation 4:7. The description of the four living creatures, also known as the tetra-morphs, in both Ezekiel's and John's visions, often surround 'Christ in Majesty' in Christian iconography. 

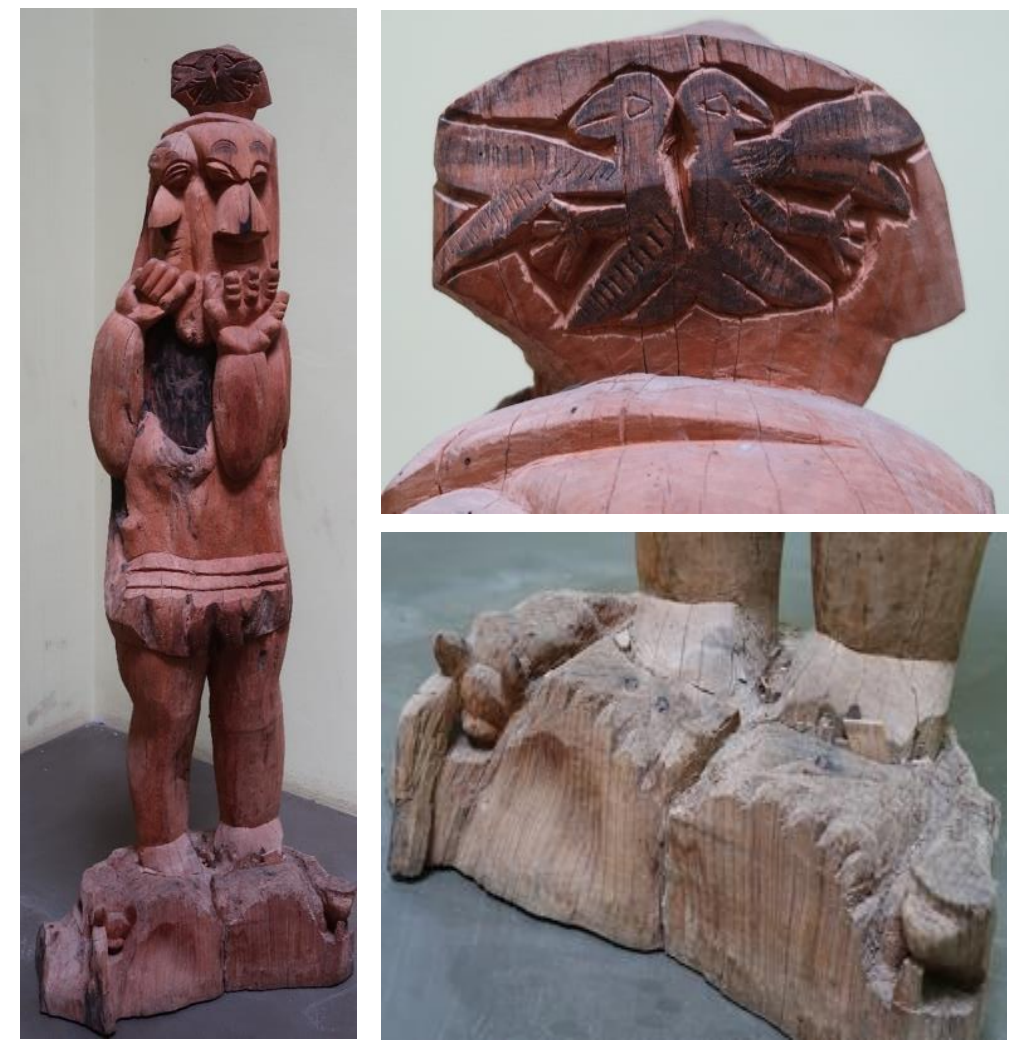

Figure 4: Left: God and Christ, top right: detail of double-headed bird, bottom right: detail of ox, bird, and lion. Photograph: Raita Steyn, courtesy Johannesburg Art Gallery.

The prophet Ezekiel must have been close to Hlungwani's heart as Ezekiel was God's prophet who criticized his people for their corruption and other sins. Hlungwani himself prophesied "the coming of an Apocalypse, which would result in man's salvation, an ultimate victory over evil" (Steyn, 2019: 182). Once there is peace, there will be a rural home- a "New Country home of God and Christ' - on an acropolis site overlooking Mbhokota village in Gazankulu" (Rich, 1989: 27). This, in Hlungwani's mind, is a place where God and Christ will dwell with people for eternity. This is also the reason why Hlungwani made two altars for the New Jerusalem site, an Altar of God and an Altar of Christ. According to Hlungwani, the old world "has come to an end in 1984", and the New World (or New Jerusalem) appeared in 1985, after "Satan has been thrown in the Pit" (Revelation 20:3; Schneider, 1989: 62) - ending with the vision of the Great White Throne of Judgment. In Chapter 21, in his vision John describes how the Glory of New Jerusalem comes down from Heaven to Earth.

Then I saw 'a new heaven and a new earth,' for the first heaven and the first earth had passed away, and there was no longer any sea. I saw the Holy City, the new Jerusalem, coming down out of heaven from God, prepared as a bride beautifully dressed for her husband. And I heard a loud voice from the throne saying, 'Look! God's dwelling place is now among the people, and he will dwell with them. They will be his people, and God himself will be with them and be their God.' (Revelation 21:1-3) 


\section{iii. Hlungwani's ancestors: Cain, son of man}

Hlungwani was well acquainted with the Book of Ezekiel and the Book of Revelation, be it from oral tradition, biblical and non-biblical literatures, images, sayings, and/or expressions. Reverend Théo Schneider affirmed that Hlungwani knew the Bible well recalling that during one of their conversation, the prophet-artist "made no less than 37 references to specific biblical passages, in the form of verbatim quotations or clear allusions ..." (Schneider, 1989: 12 and n.1 and 3).

The relation between Ezekiel 33-35 and Revelation 21-22 is also evident in Hlungwani's wooden panel titled Cain and Abel (Figure 5), as it incorporates motifs, images, and mysterious phrases from these two Books. In this panel, the numbers '33, 34, and 35' appear in three places on the panel. Apart from these numbers, figures '21 and 22' are also clearly visible, whereas numbers ' 1 and 2 ' are carved out a few times on the panel.

Six visions of the prophet Ezekiel, found in the Book of Ezekiel, are documented and structured around the following three subjects:

1) God's judgements on Israel (Chapters 1-24)

2) God's judgement on the nations (Chapters 25-32)

3) The restoration of the land and Israel's future blessings (Chapters 33-48).

After the destruction of Jerusalem in 587 BC, Ezekiel became the nation's 'guard' and refugeeconsoler, while prophesying God's promise to return the people to their homeland and restore the Temple and the throne of David.

Ezekiel, Chapter 33, must have been very important for Hlungwani as it describes the visions of restorations and is, according to Buitenwerf (2007: 3), the turning point of the Book of Ezekiel. Chapters 33-35 start with the Lord speaking to Ezekiel and calling him "Son of man". Taking "Son of man" literally, then "Son of man" refers to Cain and Abel, the first and second sons of Adam the first man.

Could Hlungwani's earthly classification of Adam's sons, Cain and Abel (numbers one and two respectively) be interpreted as a reflection, but not an equivalent, of the heavenly hierarchical arrangement of the first- and second-born sons of God, that is, Gabriel and Christ? Hlungwani would obviously be number three (Markovitz 1989), and "in between the two" worlds. It can be argued that Hlungwani concealed worldly power in religious terms. In explaining mystification and worldly realisms in terms of cosmic terms, Keesing (1981: 296) adds that "it disguises political power in terms of sacredness, in populating the universe with ancestors or gods or spirits for whom powerful humans act as intermediaries, in defining human powers as superhumanly conferred, and human rules as imposed by supernatural beings."

In Hlungwani's panel Cain and Abel, Cain is portrayed as powerful and large, while Abel is much smaller. Number ' 1 ' is carved below Cain's legs and number '2' below Abel's. In Hlungwani's theology, Cain played a more prominent role than Abel. According to Maluleke (1991: passim) and Nettleton, Hlungwani based "his theology on a distinction between Christianity practised by the descendants of Cain (blacks), as opposed to the false version of the Bible inherited by Abel's descendents (whites)" Nettleton (2009: 59). 


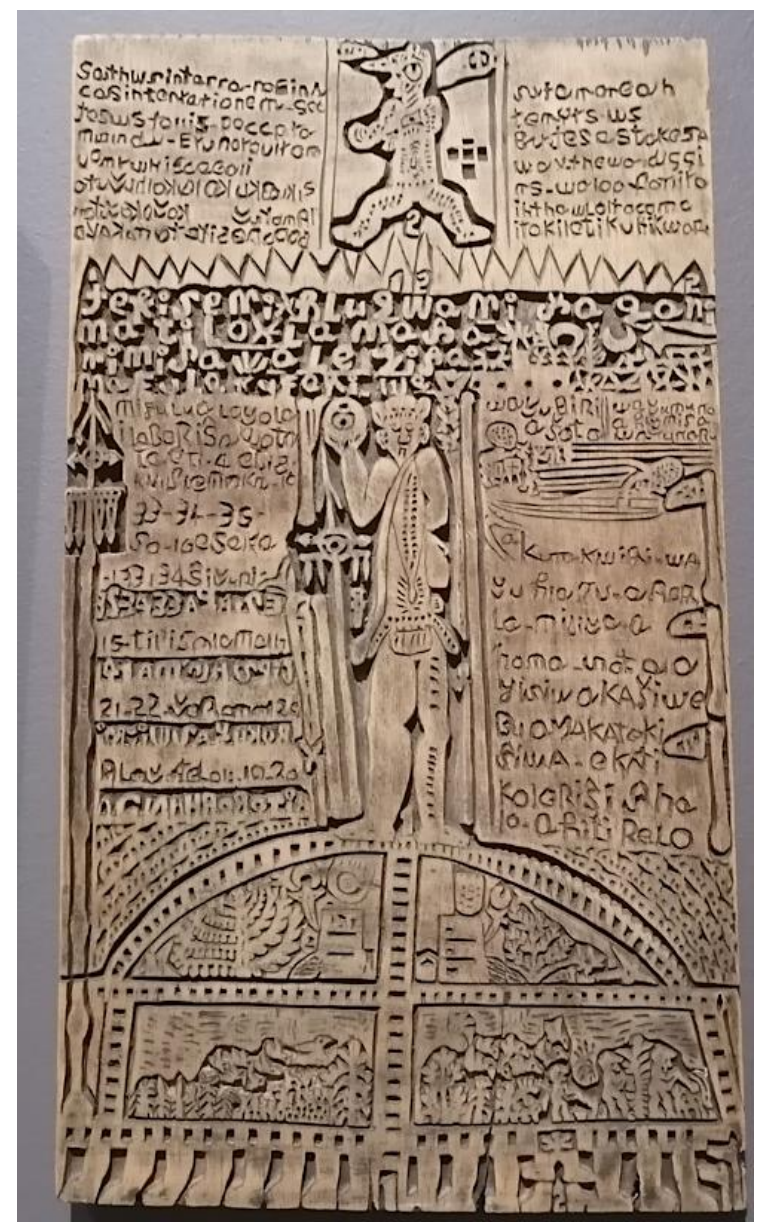

Figure 5: Wooden panel: Cain and Abel. Photograph: Raita Steyn, courtesy Norval Foundation,

\section{An attempt to reconstruct Hlungwani's 'theology'}

Hlungwani's apocalyptic vision of a New Jerusalem consists of buildings and sculptures, in which he articulates redemption through the reconciliation of opposites, and the unification of divine forces (Coetzee, 1996: 89,103,106; Nettleton, 2009: 66). During an interview with Lesley Spiro (1992: 71-72), Hlungwani explained the symbolic meaning of his sculptures. The Altar of God, Gabriel, God and Christ, Metal Cross, Crucifix, Solar Arc, and Fish belong to the same ideology of his "new country philosophy" whereby Hlungwani, referring to Revelation Chapters 18-22, "described Michael Star as representative of the 'New Country"' (Spiro, 1992: 72; Steyn, 2019: 184). In the book of Revelation, it is Michael, the Archangel, who leads God's armies against Satan and his armies during the heavenly war. Yet, it is also clear that in Hlungwani's theology, Gabriel is more important than Michael, although the latter takes his place as Michael Star, who is also a guide (Steyn, 2019: 186). One may note that in Islam, Gabriel is also number one, while Michael is number two (Kasser, Meyer \& Wurst, 2006: 40). During the creation of Adam, God first sent the angel Gabriel to fetch clay to form man, afterwards He sent Michael. It is also said that on Prophet Muhammad's deathbed, the prophet stated that Gabriel had to be the first to pray for him and Michael the second. The same idea is expressed in the so-called Gospel of Judas, when Judas asks Christ whether the human spirit also dies. In his answer, Christ said: "This is why God ordered Michael to give the spirits of people to them as a loan, so that they might offer service, but the Great One ordered Gabriel to grant spirits to the great generation with no ruler of it - that is, the spirit and the soul." (Kasser, Meyer \& Wurst, 2006: 40). 
Maluleke writes that the New Jerusalem and its altar, Hlungwani's centre of the world, his meeting point of heaven and earth, epitomises everything that he always prophesied about the new world. New Jerusalem and its altar embodies spiritual newness capable of inviting the Lord on earth when the time arrives (Maluleke, 1991: 56-57):

At this sanctuary, which he called New Jerusalem, his followers could gather. It was here that Hlungwani made his sculptures, as part of his sanctuary and as images to instruct his followers. The altars of New Jerusalem were irregular cairns of stones supporting carved images of wood and metal crosses, and on the main altar stood a tall structure resembling an aerial mast, suggesting direct communication with God. Other carvings stood independently within the large stone enclosures, some representing well-known Biblical figures, other images drawn from his personal theology. (Rankin, 1998: 43).

Hlungwani's celestial hierarchy can be intuited through (i) the position his works occupied in their original New Jerusalem setting, (ii) cues associated with specific sculptures (such as numbers) (iii) the size of figures, (iv) his own behaviour and attire, and (v) his interviews.

First, we should consider the two altars, Altar of God and Altar of Christ

\section{Altar of God}

Hlungwani created numerous sculptures that he placed on his Altar of God (Figure 6): Christ, Abel, Cain, Cain's Aeroplane, Angel Gabriel (II), Shangaan Warrior I, Shangaan Warrior II, Shangaan Warrior III, God and Christ Panel I, God and Christ Panel II, 'Map' for God and Christ, and Jonah's Fish. The Aerial to God was originally part of this altar. The Shangaan warriors were consciously placed together as soldier saints or martyrs connected with the military to protect the Altar of God. Many Christians believe that saints are able to intercede on behalf of mankind with God, and I believe that Hlungwani intentionally uses his Shangaan warriors in a similar manner. Leibhammer and $\mathrm{Nel}$ (Burroughs et al, forthcoming: 167), believe that:

The inclusion of the cohort of small Shangaan warriors on the altar is significant as these figures connect to Hlungwani's identification as a descendent of these fearsome fighters who migrated into the region in the late nineteenth century. He places them alongside Christ, The Angel Gabriel, Cain and Abel - their Christian compatriots.

Indeed, an Early Christian military saint (also soldier saint) or martyr defending the Christian faith was an Athleta Christi (Champion of Christ). ${ }^{2}$ It is therefore not surprising that Hlungwani created sculptures of his athletes titled, Christ Playing Footbal $\beta$ and Champion Man. Could Hlungwani possibly have created his Athleta Christi to protect the Altar of Christ? Leibhammer and $\mathrm{Nel}$ (Burroughs et al, forthcoming: 167) affirm that these "Shangaan figures with their shields, sticks and maces, are true warriors, yet they also compellingly hold books and tablets, weapons of a different order, in their roles as carriers and defenders of a hybrid or syncretic belief."

\footnotetext{
${ }^{2}$ Since the $15^{\text {th }}$ century the title Athleta Christi 'Champion of Christ' became a political one, given by the Popes, such as Innocent VI and Pius II, to men who led military campaigns to defend Christianity against Islam, such as Louis I and John Hunyadi of Hungary.

${ }^{3}$ One of the Christ Playing Football -sculptures is part of the Altar of Christ.
} 


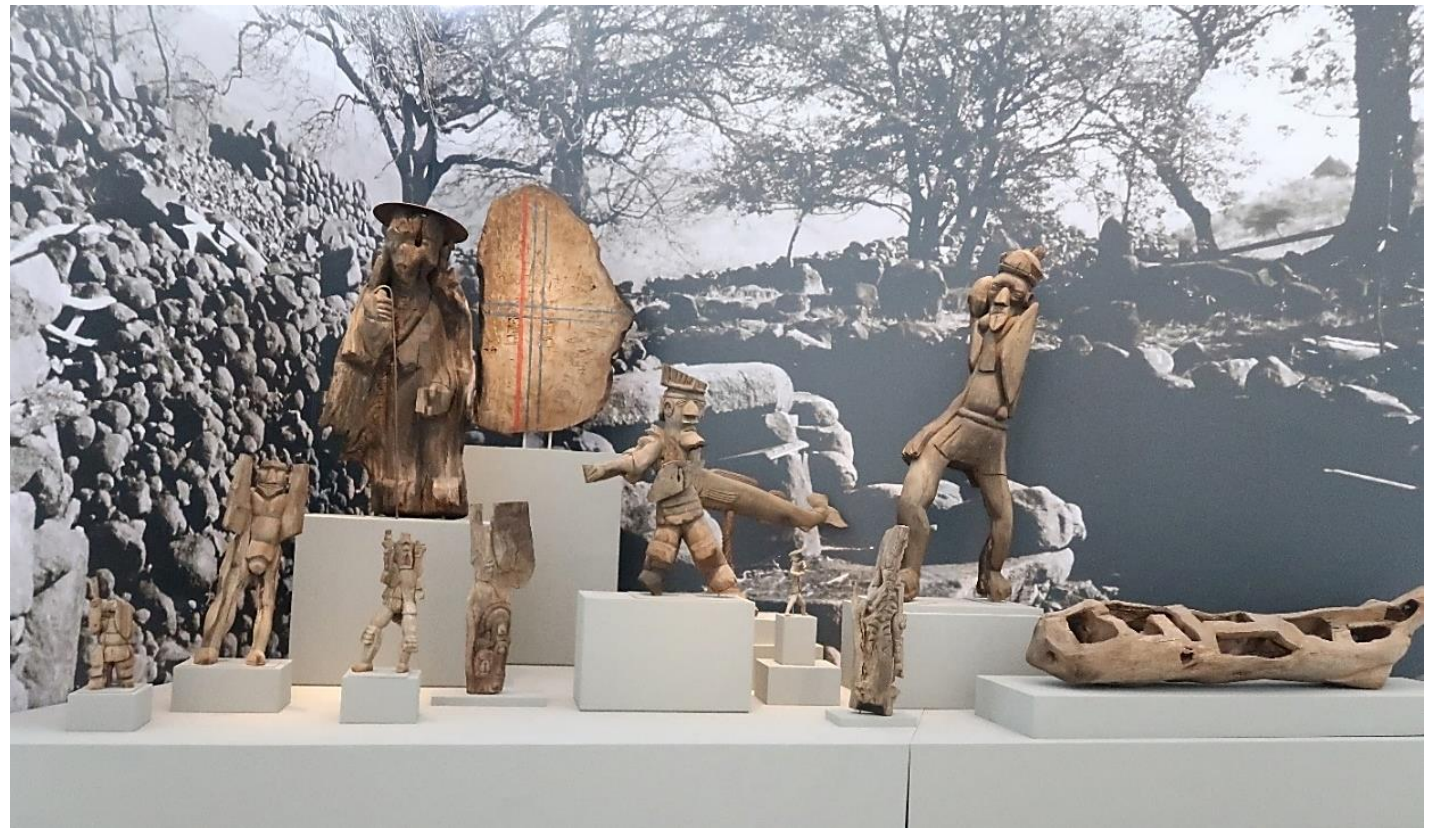

Figure 6: Altar of God. Photograph: Raita Steyn, courtesy Norval Foundation.

\section{Altar of Christ}

The Altar of Christ (Figure 7) is significantly smaller than the Altar of God with fewer sculptures on it in its original setting: Angel Gabriel (III), Salmon Fish, Solar Arc, Metal Cross, Christ Playing Football, and God. Shaka's Shield, a large carved wooden shield with a reddish colour was originally part of this assemblage but is now lost. According to Leibhammer and $\mathrm{Nel}$ (Burroughs et al, forthcoming: 171), it was "Hlungwani's practice to preach from this altar, which served as a 'pulpit' with its curved bough or "arc" acting as a framing device."

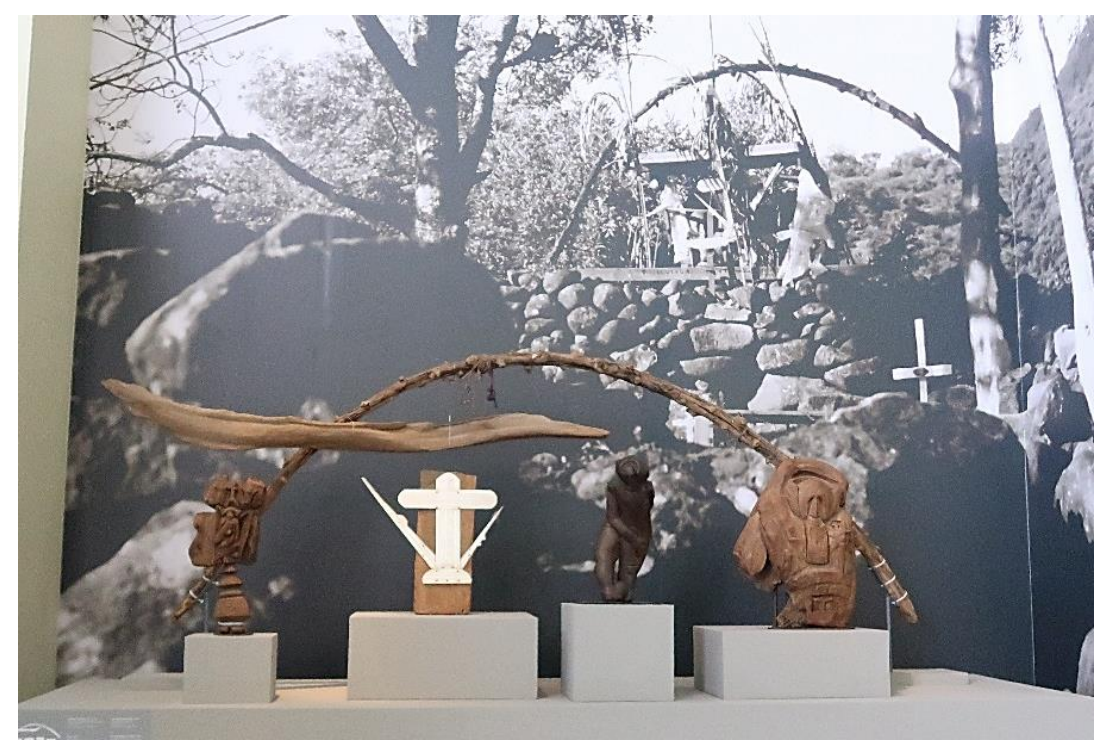

Figure 7: Altar of Christ. Photograph: Raita Steyn, courtesy Norval Foundation. 


\section{Celestial hierarchy}

Hlungwani's Shangaan warriors, Christ, God, Gabriel and Cain are all part of the Altar of God and Altar of Christ and guard the most important place at New Jerusalem. The sculptures on the Altars 1 and 2 and the separate sculptures, which I have discussed above, together give the following celestial hierarchy:

1. God - on top (aerial to God), followed by

2. Christ (and His symbolic expressions, such as crosses and fish)

3. Archangels Gabriel and Michael ${ }^{4}$

4. Prophets from the Old Testament

5. The Shangaan Warriors

6. Cain and Abel - our arch-ancestors (biblical themes)

These, together with his other sculptures, I compare to the hierarchical placement of importance of the Byzantine icons in the following table:

\begin{tabular}{|l|l|}
\hline \multicolumn{1}{|c|}{ Sculptures at New Jerusalem } & \multicolumn{1}{|c|}{ Byzantine icons } \\
\hline 1. Sculptures of God the Father & 1. Icons of Christ \\
2. Sculptures of Christ (and His & 2. Icons of Mary \\
symbolic expressions) & 3. Icons of angels and prophets \\
3. Sculptures of Archangels Gabriel & 4. Icons of apostles and evangelists \\
and Michael & 5. Icons of saints \\
4. Sculptures of prophets & 6. Icons referring to biblical themes \\
5. Sculptures of warriors & \\
6. Sculptures referring to biblical & \\
themes &
\end{tabular}

Table 1: Hierarchical order of the sculptures compared to the Byzantine icons

The above table illustrates the hierarchical similarities between the themes of Hlungwani's sculptures and those of the Byzantine icons. What is missing in Hlungwani's collection is a sculpture of the Virgin Mary. Although Hlungwani created most of his sculptures of men, Mary was indeed close to his heart, literally and figuratively speaking.

On his woollen necklaces, Hlungwani has three crosses and the medicine bottle. He says one cross is for God, one is for Jesus and the other is for Mary the Virgin. The medicine bottle is the token of his ancestry. (Maluleke 1991: 48).

Hlungwani has also given himself a place in this hierarchy; Christ's face was perhaps replaced by his own face (Maluleke, 1991: 20). In his interviews, Hlungwani names himself "the third son of God", but he also controversially claimed that Gabriel was the first-born of God, and on another occasion, he called Satan the first born (Maluleke, 1991: 40). This celestial hierarchy brings some important questions to the fore: "What about the Holy Spirit? Where is He placed?" One may accept - with some degree of certitude - that the Holy Spirit is represented as the bird in some of his works, such as God and Christ and in the Crucifixes. Yet, where do

\footnotetext{
${ }^{4}$ The sculpture Michael Star (Archangel Michael), made in 1989 and currently in the Johannesburg Art Gallery Collection, is a separate artwork, yet in an interview with Lesley Spiro (1992: 72 note 20), Hlungwani said that "Michael Star was the representative of the "New Country". During my visit at the Johannesburg Art Gallery and at the Norval Foundation, I have also seen, Michael Star, shaped as a Bethlehem Star, carved on God's breast (Altar of Christ) and upside down behind the sculpture of Cain (Altar of God).
} 
the warriors fit in and what is their role? The description 'Shangaan' comes - without doubt from his cultural background, but they are in the context of the hierarchy referring to the ancestors, who watch over him and the living.

One may ultimately also see in these works allusions to the fighting referred to in the Book of Ezekiel, the Apocalypse of Saint John, and the Heavenly war against Satan and his angels in the Book of Revelation. Considering that Satan was often referred to in his interviews, one needs to ask if Satan has a place in Hlungwani's cohort of sculptures. Some of his sculptures refer to the wound on his leg, and also to God's leg, who passed him by, as previously mentioned in this article. Hlungwani has stated that Satan shot arrows into his legs, and as a result he considered suicide. However, God - in an epiphany - saved him and gave him three promises, to which I have already referred. Thus, Satan does play a role; a negative one, which God nevertheless transforms into a positive one.

\section{Hlungwani's New Jerusalem}

Hlungwani built his open-air church, which he called New Jerusalem (Yesu Galeliya One Apostol in Sanyoni Alt and Omega) on top of a hill in Mbhokota, over existing late iron age ruins (Maluleke 1991: 31 ) or Venda ruins ${ }^{5}$ (Nettleton 2009: 54,67 ). It was a "conscious" decision (Nettleton 2009: 55-56) that united the living with the ancestors, the seen with the unseen. These ruins were indeed sacred to Hlungwani; when his sculptures were sold to the Johannesburg Art Gallery and to Wits University, he insisted on bringing stones from the ruins at Mbhokota to be placed with the altars in their new locations (Spiro, 1992: 69).

The hill-top acropolis had two altars, different sections, streets, and many sculptures. The mast or 'aerial to God' was the central point. All these structures were created as a means by which to communicate with God. "Mount Tabor has for centuries [been] a place of Christian pilgrimage and is also the site of the Church of the Transfiguration" (Nicolaides 2020: 4), similarly Hlungwani considered the New Jerusalem as a place for pilgrimage and God's dwelling.

The New Jerusalem at Mbhokota looked like an ancient fort, a temple in fact, for men to worship God, as the women worshipped at 'Kanana'. For Hlungwani, his New Jerusalem was sacred, it was the Lord's holy house and not the meeting place for worshippers. The worshippers gathered not in the Lord's Temple (New Jerusalem) as such, but in Hlungani's garden. When he moved to Kanana, the gathering took place in the open air under a Marula tree, but when it stormed, they went in to his workshop (Maluleke 1991: 31-33).

Hlungwani made a conscious distinction between the New Jerusalem structure and Kanana (New Canaan), which was gender-related. The first, based on the Tsonga's traditional belief, was designated for men and the second for women (Maluleke, 1991: 44). Hlungwani did not persist in his original intentions.

\section{Financial temptation}

In due course, the financial temptation became too great, and he sold almost all his sculptures from the New Jerusalem's Altars This new phase in his life made him famous, but it did not affect his beliefs or his 'theology', judging from his interviews.

However, the New Jerusalem as a religious site, did not fulfil its aims after he started selling the sculptures, the building remained uncompleted. Far from becoming a Central Temple or a

\footnotetext{
${ }^{5}$ According to Nettleton (2009: 55) (referring to Huffman 1996), Hlungwani's New Jerusalem "was built on the ruins of an ancient stone-walled settlement of the type used by Venda-speakers in the area over the past 1000 years".
} 
Place for Pilgrimage, after the two altars were moved, the stone structures became dilapidated and overgrown by nature (Figure 8). While Hlungwani's 'theolgy' and beliefs did not change, the New Jerusalem did not retain its intended function, and no longer played a part in Hlungwani's envisaged scheme. However, Hlungwani still held his services in his new yard under the Marula tree - a "morning mass and an "afternoon mass", according to Maluleke (1991: 34). In this house-church, Hlungwani was an attaining-performing priest, a real spiritual leader.

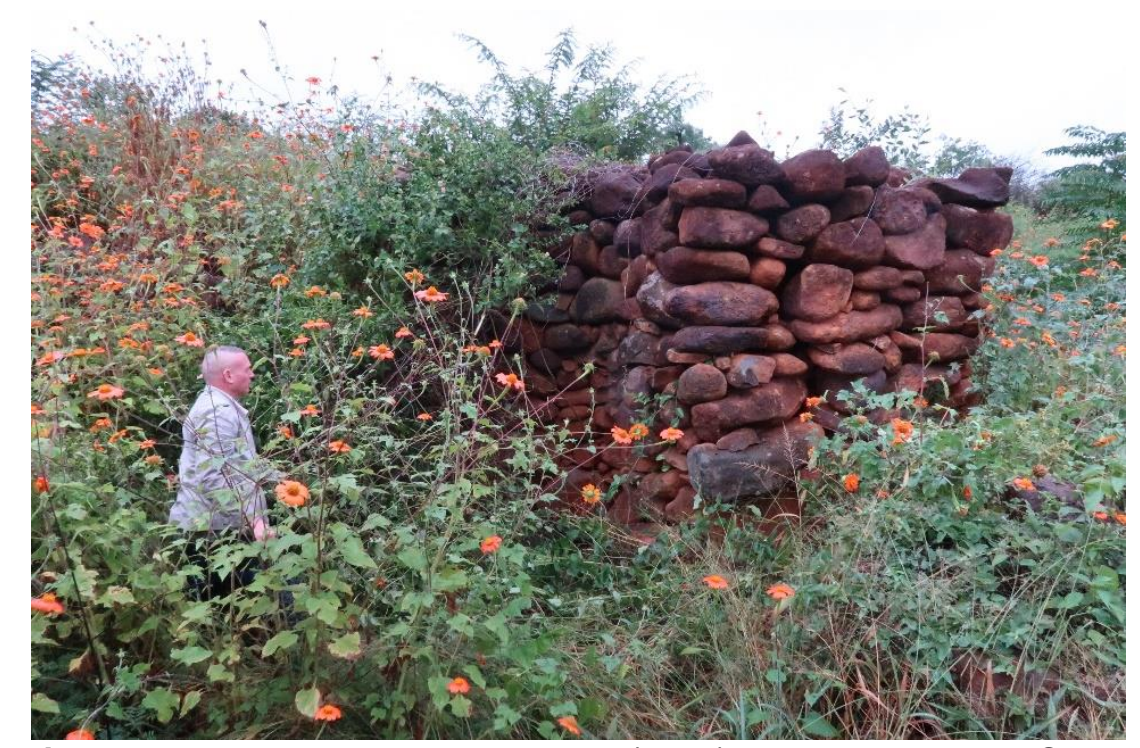

Figure 8: New Jerusalem at Mbhokota (2019). Photograph: Raita Steyn.

\section{Conclusion}

In this article, I have given a short overview of Hlungwani's life and work, thereby concentrating on his calling and the "revealed" religious instructions he believed he had received from God. Firstly, Christ revealed Himself to Hlungwani and promised him that he would be serving God his whole life. This happened, and moreover, the revelations gave form and artistic creativity to him, leading to his crucifixes and different sculptures (Crucifix I \& IV, Cain and Abel wooden panel, Christ and God, Altar of God and Altar of Christ).

Hlungwani's sculptures and some of his interviews exalted him as the third son of God, a brother of Jesus. Three crosses around his neck attested of his belief in God, Jesus, and Mary. The distinction he made between a gathering place for men and for women, makes one suppose that his religion was - as are the main churches up until now - male-oriented. God and Jesus, Gabriel and Michael, and the warriors are all men. Only Mary finds a place, although - one may say - a humble one.

I thereby have also examined the African background which Hlungwani united in a synthetic and/or symbolic way with his own Shangaan/Tsonga traditions and some dogmas coming from the African Zionist churches, which finally led to the creation of his own Apostol in Sayoni - Alpha and Omega Church, and the Temple in his New Jerusalem. The latter, a 'pilgrim' temple, which he built in Mbhokota, symbolized his original religious aim. Hlungwani's belief resulted itself in a combination of art, religion, and philosophy. The future was a New Jerusalem, not the building, but an ideal, which was Christian, but with an African accent. The New Jerusalem was viewed as a representation articulating the artist's optimism for a new world. Undeniably, there was also a political philosophy to his work, his belief introducing a New Country philosophy, referring to the Old World (Apartheid) and the 'New Country' (PostApartheid). 
It is important to note that we do not find any traces of negative or aggressive racism in his world view or works. It also became clear that his "credo" and his activities changed when he started to sell his works, which led to the abandoning of the New Jerusalem. At that period, it appears that financial gain became one of the main factors of his actions and perhaps/probably his creativity.

I furthermore have analysed his concepts of God and Christ, and their relations with the archangels, with his 'children', his ancestors, and with his Shangaan/Tsonga connections, such as his Shangaan warriors as protectors of the altars and soldiers of God. This led to my attempt to reconstruct Hlungwani's theology.

The New Jerusalem was viewed as a representation articulating the artist's optimism for a new world and a religion with political undertones, i.e. a just political system.

With acknowledgement to the South African National Institute of the Humanities and the Social Sciences (NIHSS) for financially supporting the research presented in this special edition. (Project CRP20-1032: African Oral art in image-text objects: Cultural translations of precolonial memories and remains)

\section{References:}

Anderson, A. (2000). Zion and Pentecost: The Spirituality and Experience of Pentecostal and Zionist/Apostolic churches in South Africa, Pretoria: UNISA Press.

Becker, R. (1989). Visions and the Viewer. In Jekiseni Hlungwani Sangani: An Exhibition, edited by Ricky Burnett. Johannesburg: The Communications Department, BMW (South Africa), 20-23.

Buitenwerf, R. (2007). The Gog and Magog Tradition in Ezekiel 2020:8. In The Book of Ezekiel and his Influence De Jonge, H.J.; Tromp, Johannes (eds). Ashgate Publishing.

Cavallo, G. (2013). Mademonio and Angels: The Spirit World According to Zion Churches in Maputo and Matola, Southern Mozambique,

https://www.academia.edu/29213067/Mademonio_and_Angels_The_spirit_world_according to_Zion_churches_in_Maputo_and_Matola_Southern_Mozambique (accessed Āugust 16, 2018).

Coetzee, M. (1996). The Artist as a Visionary. A Consideration of Jackson Pollock, Joseph Beuys and Jackson Hlungwani as Visionary Artists. MA dissertation. University of Natal.

Hayashida, S.L. (2000). Mission and the Visual Expressions of the Gospel in the Sculpture of Jackson Hlungwani. MA dissertation. University of South Africa.

Huffman, T. (1996). Snakes and Crocodiles: Power and Symbolism in Ancient Zimbabwe. Johannesburg Wits University Press.

Kasser, R.O. (ed.), Meyer, M., \& Wurst, G. (2006). The Gospel of Judas with additional commentary by B. D. Ehrman, Washington.

Keesing, R.M. (1981). Cultural Anthropology, a Contemporary Perspective, Canberra.

Le Roux, M. (2003). The Lemba, a Lost Tribe of Israel in Southern Africa? ABC Press: Pretoria. 
Leibhammer, N \& Nel, N. (forthcoming). Jackson Hlungwani Alt and Omega: Sculptures that Teach. In Jackson Hlungwani: Alt and Omega, Burroughs, E, Leibhammer, N \& Nel, N., (eds): 110-235.

Maluleke, M.J. (1991). God's Own Artist. University of the Witwatersrand Art Galleries, Unpublished manuscript.

Markovitz, M. (1989). Carving a Niche, in Sunday Star, November 19: 23.

Nettleton, A. (2009). Jackson Hlungwani's altars: an African Christian theology in wood and stone, Material Religion, 5(1), 50-69. DOI: 10.2752/175183409X418748 http://dx.doi.org/10.2752/175183409X418748 (accessed 13 August 2017).

Nicolaides, A. (2020). The Transfiguration as a Divine Mystery in Orthodoxy, Pharos Journal of Theology, 101: a 2

Rankin, E. (1998). From Altars to Art Galleries: The Sculpture of Jackson Hlungwani. In Vuka 3(1), 43-48.

Rich, P. (1989). The New Jerusalem. In Jekiseni Hlungwani Sangani: An Exhibition. In Ricky Burnett (ed). Johannesburg: The Communications Department, BMW (South Africa), 27-30.

Schneider, T. (1989). The Star on the Colt. In Jekiseni Hlungwani Sangani: An Exhibition, edited by Ricky Burnett. Johannesburg: The Communications Department, BMW (South Africa), 8-13.

Spiro, L. (1992). Fish Out of Water?: Some thoughts on an 'Installation' of Works by Jackson Hlungwani at the Johannesburg Art Gallery. Unpublished manuscript in the Archives of the Johannesburg Art Gallery.

Steyn, R. (2008). Archangel Michael as 'Icon' in the Byzantine and Post-Byzantine Periods. MA Dissertation, University of Johannesburg.

Steyn, R. (2019). The Archangel Michael in Limpopo: the sculptor Jackson Hlungwani and the Angel-Star of the Ngoma Lungundu epic. In The Archangel Michael in Africa: History, Cult and Persona, Ingvild Saelid Gilhus, Alexandros Tsakos, Marta Camilla Wright (eds). Bloomsbury Academic: Great Britain.

Steyn, R. \& Burroughs, L. (forthcoming). The Influence of African Christianity on Hlungwani's New Jerusalem and his Sacred Sculpture. In Jackson Hlungwani: Alt and Omega, Burroughs, E, Leibhammer, N \& Nel, N., (eds): 34-95.

Van Zyl, J. (1991). Jackson Hlungwani: The Little Donkey who Sculpts, in Style (Oct), 116119.

Wallis-Budge, E.A. (1932). The Queen of Sheba and her only Son Menyeliek (I), London: Oxford University Press.

West, M. (1975). Bishops and Prophets in a Black City. African Independent Churches in Soweto, Johannesburg. David Philip Publisher: Cape Town. 